\title{
Respiration of Mediterranean cold-water corals is not affected by ocean acidification as projected for the end of the century
}

\author{
C. Maier ${ }^{1,2}$, F. Bils ${ }^{1,2,3}$, M. G. Weinbauer ${ }^{1,2}$, P. Watremez ${ }^{4}$, M. A. Peck ${ }^{3}$, and J.-P. Gattuso ${ }^{1,2}$ \\ ${ }^{1}$ Laboratoire d'Océanographie de Villefranche, UMR7093, CNRS-INSU, BP 28, 06234 Villefranche-sur-mer, France \\ ${ }^{2}$ Université Pierre et Marie Curie-Paris 6, Observatoire Océanologique de Villefranche, 06230 Villefranche-sur-mer, France \\ ${ }^{3}$ University of Hamburg, Institute for Hydrobiology and Fisheries Science, Olbersweg 24, 22767 Hamburg, Germany \\ ${ }^{4}$ Agence des Aires Marines Protégées, 16 quai de la Douane, 29229 Brest, France
}

Correspondence to: C. Maier (maier.conny@gmail.com)

Received: 19 April 2013 - Published in Biogeosciences Discuss.: 2 May 2013

Revised: 12 July 2013 - Accepted: 22 July 2013 - Published: 27 August 2013

\begin{abstract}
The rise of $\mathrm{CO}_{2}$ has been identified as a major threat to life in the ocean. About one-third of the anthropogenic $\mathrm{CO}_{2}$ produced in the last $200 \mathrm{yr}$ has been taken up by the ocean, leading to ocean acidification. Surface seawater $\mathrm{pH}$ is projected to decrease by about 0.4 units between the pre-industrial revolution and 2100 . The branching cold-water corals Madrepora oculata and Lophelia pertusa are important, habitat-forming species in the deep Mediterranean Sea. Although previous research has investigated the abundance and distribution of these species, little is known regarding their ecophysiology and potential responses to global environmental change. A previous study indicated that the rate of calcification of these two species remained constant up to $1000 \mu \mathrm{atm} \mathrm{CO}_{2}$, a value that is at the upper end of changes projected to occur by 2100 . We examined whether the ability to maintain calcification rates in the face of rising $p \mathrm{CO}_{2}$ affected the energetic requirements of these corals. Over the course of three months, rates of respiration were measured at a $p \mathrm{CO}_{2}$ ranging between 350 and $1100 \mu \mathrm{atm}$ to distinguish between short-term response and longer-term acclimation. Respiration rates ranged from 0.074 to $0.266 \mu \mathrm{mol} \mathrm{O}_{2}$ (g skeletal dry weight $)^{-1} \mathrm{~h}^{-1}$ and 0.095 to $0.725 \mu \mathrm{mol} \mathrm{O}_{2}$ (g skeletal dry weight $)^{-1} \mathrm{~h}^{-1}$ for $L$. pertusa and $M$. oculata, respectively, and were independent of $p \mathrm{CO}_{2}$. Respiration increased with time likely due to regular feeding, which may have provided an increased energy supply to sustain coral metabolism. Future studies are needed to confirm whether the insensitivity of respiration to increasing $p \mathrm{CO}_{2}$ is a general feature of deep-sea corals in other regions.
\end{abstract}

\section{Introduction}

Cold-water corals form unique, deep-sea habitats containing a high biodiversity of organisms (Roberts et al., 2006). The habitat-forming cold-water corals Lophelia pertusa and Madrepora oculata are found in relatively deep waters at temperatures and salinities between 4 and $12^{\circ} \mathrm{C}$ (Roberts et al., 2006) and 31.7 and 38.8 (Davies et al., 2008), respectively. Recent work on the distribution and abundance of these cold-water corals in the Mediterranean Sea (Taviani et al, 2005b; Freiwald et al., 2009; Orejas et al., 2009) indicates that they are found at depths below $200 \mathrm{~m}$, at relatively warm (and stable) temperatures $\left(12.5\right.$ to $\left.13.5^{\circ} \mathrm{C}\right)$ and high salinity (38 to 39) (Freiwald et al., 2009; Tursi et al., 2004). Biogeographic considerations indicate that the cold-water corals in the Mediterranean Sea occur at the warm edge of their range in thermal tolerance (Davies et al., 2008). M. oculata is more abundant than $L$. pertusa in the region, which suggests that the former may be better adapted than the latter to warmer temperature and more saline waters (Taviani et al., 2005a). A general decline in the presence of Mediterranean cold-water corals has been reported during the post-glacial time (Delibrias and Taviani, 1985), and appears to be more pronounced for L. pertusa than for M. oculata.

The oceans play a critical role in mitigating the effect of increased production of greenhouse gasses on global climate by removing $\sim$ one-fourth to one-third of anthropogenic $\mathrm{CO}_{2}$ from the atmosphere (Khatiwala et al., 2009; Sabine et al., 2004). The downside of this process is that, once dissolved in seawater, $\mathrm{CO}_{2}$ is a weak acid which reduces seawater 
pH causing ocean acidification (Caldeira and Wickett, 2003; Gattuso et al., 1999). This process also increases the concentrations of bicarbonate ions $\left(\mathrm{HCO}^{3-}\right)$ and dissolved inorganic carbon $\left(C_{\mathrm{T}}\right)$ and decreases the concentration of carbonate ions $\left(\mathrm{CO}_{3}^{2-}\right)$. The saturation state of calcium carbonate, $\Omega$, is a measure of the solubility of carbonate minerals (e.g. calcite $\left(\Omega_{\mathrm{c}}\right)$ or aragonite $\left(\Omega_{\mathrm{a}}\right)$ ) in seawater (Kleypas et al., 1999; Feely et al., 2004; Cao et al., 2007), and provides a good indicator of whether calcifying organisms can build and maintain their exoskeletons (e.g. corals) and shells (e.g. pteropods). Calcium carbonate dissolution is favoured when $\Omega$ is below 1 , while calcium carbonate precipitation is favoured when it is above 1 . The saturation state decreases with increasing pressure (water depth) and decreasing temperature; hence, $\Omega$ is lower at higher latitude (colder) and deeper waters than in lower latitude (warmer) and shallower waters (Orr et al., 2005). Calcifying organisms at high latitudes and/or deeper depths will be the first to be subjected to seawater favouring carbonate dissolution $(\Omega<1)$. At the end of the century, $\Omega_{\mathrm{a}}$ is projected to be $<1$ within $>70 \%$ of the present habitat of cold-water corals (Guinotte et al., 2006 \#2578).

Previous experiments examining the effect of ocean acidification on L. pertusa and M. oculata suggest that their rates of calcification remain positive even in waters where $\Omega_{\mathrm{a}}$ is $<1$ (Maier et al., 2009; Thresher et al., 2011; Form and Riebesell, 2012). Moreover, recent studies (Form and Riebesell, 2012; Maier et al., 2012, 2013) reported that calcification rates of these species remained positive at a partial pressure of $\mathrm{CO}_{2}\left(p \mathrm{CO}_{2}\right)$ of $1000 \mu \mathrm{atm}$, a value that is at the high end of projected changes by 2100 (IPPC, 2007). Calcification is an energy-demanding process (Goreau, 1959; Allemand et al., 2004), and it is likely that the mechanism(s) responsible for these species maintaining positive rates of calcification at high $p \mathrm{CO}_{2}$ (lower seawater $\mathrm{pH}$ ) would be reflected in higher energetic costs. For example, it has been suggested that M. oculata and L. pertusa are able to regulate their internal $\mathrm{pH}$ over a large gradient of $p \mathrm{CO}_{2}$ (McCulloch et al., 2012), which likely increases their metabolic requirements. Unfortunately, very little is known regarding the metabolic rate of these species. No metabolic research has been performed on M. oculata, and respiration rates have only been reported in one study on specimens of $L$. pertusa collected from the North Atlantic and maintained under variable temperature (Dodds et al., 2007). In that study, a dramatic (50\%) increase in respiration rate occurred between 9 and $11^{\circ} \mathrm{C}$ (Dodds et al., 2007), temperatures that are several degrees colder than those experienced by cold-water corals in the Mediterranean Sea.

In the present study, respiration rates were measured for two habitat-forming cold-water coral species, M. oculata and L. pertusa, from the Mediterranean Sea. Respiration rates were measured for corals maintained for both short and long periods of time at $p \mathrm{CO}_{2}$ levels ranging from ambient $(350 \mu \mathrm{atm})$ to elevated $(1100 \mu \mathrm{atm})$ levels. This study utilized the same experimental setup as a previous study demonstrating that elevated $p \mathrm{CO}_{2}$ had no effect on the rate of calcification in these two species (Maier et al., 2013). Thus, we test the hypothesis that the ability to maintain positive rates of calcification at high $p \mathrm{CO}_{2}$ is accompanied by higher energy requirements which could be expressed by increased rates of respiration.

\section{Material and methods}

\subsection{Sampling of cold-water corals and experimental setup}

Colonies of the cold-water corals M. oculata and L. pertusa were collected during the MedSeaCan cruise in June 2009 in the Lacaze-Duthiers canyon at water depths of $260 \mathrm{~m}\left(42^{\circ} 35.07^{\prime} \mathrm{N}, 03^{\circ} 24.14^{\prime} \mathrm{E}\right), 267 \mathrm{~m}\left(42^{\circ} 34.98^{\prime} \mathrm{N}\right.$, $\left.03^{\circ} 24.15^{\prime} \mathrm{E}\right)$ and $500 \mathrm{~m}\left(42^{\circ} 32.98^{\prime} \mathrm{N}, 03^{\circ} 25.21^{\prime} \mathrm{E}\right)$, using a remotely operated vehicle. Corals were transported to the laboratory and maintained in a temperature-controlled room until the start of the experiments. Branches were carefully subdivided into smaller fragments and placed into individual maintenance vials of $4.5 \mathrm{~cm}$ inner diameter and a volume of ca. $300 \mathrm{~mL}$ (Table 1). Surface water with a salinity of 38 was pumped into two $110 \mathrm{~L}$ storage tanks and maintained at $11^{\circ} \mathrm{C}$ in the temperature-controlled room. Water was delivered to maintenance vials at a flow rate of $32 \pm 14 \mathrm{~mL} \mathrm{~h}^{-1}$. The vials were maintained in four water baths and temperature was adjusted to $13 \pm 0.1^{\circ} \mathrm{C}$ using electronic temperature controllers (Corema) coupled with aquarium heaters (Tetratec HT75). Homogeneity of temperature was achieved by water circulation pumps (JBL Pro Flow 500, $500 \mathrm{~L} \mathrm{~h}^{-1}$ ).

Circulation in the coral maintenance vials was obtained by airlift with thin silicon tubes connected to a PVC tube $(8 \mathrm{~cm}$ long and $1.0 \mathrm{~cm}$ in diameter), which was submerged inside each of the vials. The air flow was $50 \mathrm{~mL} \mathrm{~min}^{-1}$ in every vial. Corals were fed 1 and 3 times a week with frozen krill and freshly hatched Artemia nauplii, respectively. After an acclimation period of 1 month, $p \mathrm{CO}_{2}$ was adjusted using pre-mixed air generated by high-precision mass flow controllers (MFCs, ANALYT MC-GFC17, 0-10 L for air and 0$10 \mathrm{~mL}$ for pure $\mathrm{CO}_{2}$ ) and an air compressor (Jun-Air OF30225B). Four $p \mathrm{CO}_{2}$ treatments were established: $\mathrm{A}=280 \mathrm{ppm}$ (low), $\mathrm{B}=400 \mathrm{ppm}$ (ambient), $\mathrm{C}=700 \mathrm{ppm}$ (elevated) and $\mathrm{D}=1000 \mathrm{ppm}$ (above projected) as described in Maier et al. (Maier et al., 2013).

The seawater of the water baths containing the maintenance vials was also adjusted to the intended $p \mathrm{CO}_{2}$ by bubbling with an air stone (HOBBY ceramic air diffuser, $150 \mathrm{~mm}$ in length). Prior to feeding, the seawater of the water bath was filtered (Tetratec EX 1200, $1200 \mathrm{~L} \mathrm{~h}^{-1}$ ). Any leftover food was removed via siphon to prevent bacterial respiration and the build-up of nutrients and organic matter. Corals were maintained under these conditions throughout 
Table 1. Number of samples $(N)$, number of polyps per coral fragment ( $N$ polyps), skeletal dry weight (SDW), and rates of respiration $(R)$ and calcification ( $G$, Maier et al., 2013) of coral fragments of $L$. pertusa (LP) and M. oculata (MO). Values of $R$ and $G$ of periods $T_{1}$ to $T_{4}$ were pooled.

\begin{tabular}{|c|c|c|c|c|c|c|c|c|c|c|}
\hline \multirow{2}{*}{$\begin{array}{l}p \mathrm{CO}_{2} \\
\text { treatment }\end{array}$} & \multirow{2}{*}{$\begin{array}{c}\text { Coral } \\
\text { species }\end{array}$} & \multirow[t]{2}{*}{$N$} & \multicolumn{2}{|c|}{$N$ polyps } & \multicolumn{2}{|c|}{ SDW [g] } & \multicolumn{2}{|c|}{$R\left[\mu \mathrm{molg}{ }^{-1} \mathrm{~h}^{-1}\right]$} & \multicolumn{2}{|c|}{$G\left[\mu \mathrm{molg} \mathrm{g}^{-1} \mathrm{~h}^{-1}\right]$} \\
\hline & & & mean & S.D. & mean & S.D. & mean & S.D. & mean & S.D. \\
\hline A & LP & 5 & 9.2 & 4.8 & 5.7 & 4.2 & 0.146 & 0.073 & 0.082 & 0.076 \\
\hline B & LP & 4 & 11.0 & 5.0 & 4.6 & 2.8 & 0.216 & 0.092 & 0.066 & 0.068 \\
\hline $\mathrm{C}$ & LP & 4 & 14.3 & 5.0 & 5.4 & 1.9 & 0.117 & 0.030 & 0.053 & 0.046 \\
\hline $\mathrm{D}$ & LP & 4 & 12.5 & 5.6 & 7.6 & 5.8 & 0.162 & 0.096 & 0.081 & 0.050 \\
\hline mean & LP & 17 & 11.6 & 5.0 & 5.8 & 3.8 & 0.160 & 0.078 & 0.071 & 0.057 \\
\hline A & MO & 3 & 26.7 & 8.4 & 2.6 & 1.9 & 0.193 & 0.045 & 0.117 & 0.043 \\
\hline $\mathrm{B}$ & MO & 6 & 29.3 & 7.5 & 2.0 & 1.6 & 0.483 & 0.453 & 0.166 & 0.098 \\
\hline $\mathrm{C}$ & MO & 3 & 29.3 & 10.3 & 1.8 & 0.8 & 0.450 & 0.365 & 0.113 & 0.047 \\
\hline $\mathrm{D}$ & MO & 4 & 29.5 & 11.3 & 1.5 & 1.0 & 0.577 & 0.711 & 0.169 & 0.080 \\
\hline mean & MO & 16 & 28.9 & 8.3 & 2.0 & 1.3 & 0.446 & 0.453 & 0.148 & 0.076 \\
\hline
\end{tabular}

the 3-month duration of the experiment except during incubations aimed at determining rates of respiration (next section) or calcification (Maier et al., 2013).

\subsection{Determination of respiration rates}

Two days $\left(T_{1}\right)$ after adjusting to different $p \mathrm{CO}_{2}$ levels and at about monthly intervals for 3 months $\left(T_{2}-T_{4}\right)$, rates of respiration were measured using the same coral fragments (repeated measures approach). Respiration was determined using optodes (Presens OXY-4 mini) equipped with polymer optical fibres (Presens, POF) and small sensors (5 mm diameter) placed inside the respiration vials. The respiration vials $(8 \mathrm{~cm} \times 5.5 \mathrm{~cm}$ height $\times$ diameter $)$ with a screw cap were placed on four submersible magnetic stirrers in a temperature-controlled water bath $\left(13{ }^{\circ} \mathrm{C} \pm 0.1^{\circ} \mathrm{C}\right)$. A magnet was placed below a grid on which the corals were placed during the incubations. Three vials containing coral fragments were incubated for $2.5 \mathrm{~h}$, while a separate vial, with no coral, served as blank and contained a temperature sensor (StarOddi, DST centi-T) logging every $30 \mathrm{~s}$ with an accuracy of $\pm 0.1^{\circ} \mathrm{C}$ to make sure temperature was constant during the $2.5 \mathrm{~h}$ duration of incubation. Any oxygen consumption rate within the blank, due to either minor changes in temperature or prokaryotic respiration, was subtracted from that measured in cold-water corals.

Prior to respiration measurements, $p \mathrm{CO}_{2}$ levels were adjusted in bulk seawater in $10 \mathrm{~L}$ containers by aeration with the four air- $\mathrm{CO}_{2}$ mixtures for $24 \mathrm{~h}$. Respiration rates were determined from the depletion in $\mathrm{O}_{2}$ during incubation period. Oxygen sensors were calibrated with oxygen-free $(0 \%)$ and oxygen-saturated $(100 \%)$ seawater. Oxygen consumption curves $\left(\% \mathrm{O}_{2}\right)$ were established at $30 \mathrm{~s}$ intervals over an incubation period of $2.5 \mathrm{~h}$, and respiration rates are given as $\mu$ mol $\mathrm{O}_{2}$ (g skeletal dry weight $)^{-1} \mathrm{~h}^{-1}$ (Table 1, Fig. 1). An incubation period of $2.5 \mathrm{~h}$ is relatively short with respect to the size of coral fragments and volume of seawater used, but was sufficient to detect changes in oxygen consumption and to avoid hypoxia as shown by the oxygen saturation at the end of measurements, which was always above $88 \%$ and well above $90 \%$ for most incubations.

\subsection{Carbonate chemistry}

Samples for total alkalinity $\left(A_{\mathrm{T}}\right)$ and dissolved inorganic carbon $\left(C_{\mathrm{T}}\right)$ were taken from bulk seawater $(125 \mathrm{~mL}, N=3$ for each $p \mathrm{CO}_{2}$ treatment) prior to incubation and analysed as described in Maier et al. (2012). Other parameters of the carbonate chemistry, i.e. the partial pressure of $\mathrm{CO}_{2}\left(p \mathrm{CO}_{2}\right)$, $\mathrm{pH}$ on total scale $\left(\mathrm{pH}_{\mathrm{T}}\right)$, and aragonite saturation state $\left(\Omega_{\mathrm{a}}\right)$ were calculated using $A_{\mathrm{T}}, C_{\mathrm{T}}$, a salinity of 38 , temperature of $13{ }^{\circ} \mathrm{C}$ and hydrostatic pressure of $0 \mathrm{~atm}$ using the software package seacarb running under $\mathrm{R}$ (Lavigne and Gattuso, 2011). The $p \mathrm{CO}_{2}$ cannot be adjusted during incubation. The carbonate chemistry therefore changed as function of respiration, calcification (Maier et al., 2013) and ammonium excretion (Maier et al., 2009). These changes were estimated using a stepwise approach where $A_{\mathrm{T}}$ and $C_{\mathrm{T}}$ were calculated in hourly steps for the entire duration of the $2.5 \mathrm{~h}$ incubation for each coral fragment and repeated measurements of respiration rates $\left(T_{1}-T_{4}\right)$ using the following equations:

$A_{\mathrm{T}}(t+1)=A_{\mathrm{T}}(t)-2 \times G+0.875 \times E$,

$C_{\mathrm{T}}(t+1)=C_{\mathrm{T}}(t)+R-G(2)$,

with calcification rate $(G)$, respiration rate $(R)$ and ammonium excretion rate $(E)$ in $\mu \mathrm{mol} \mathrm{kg} \mathrm{kg}^{-1} \mathrm{~h}^{-1}$. The alkalinity anomaly technique was used to determine $G$ (Maier et al., 2013) for each coral fragment and respective time interval (repeated measures $T_{1}-T_{3}$ ). This means that only data of $G$ and $\mathrm{NH}_{4}$ from Maier et al. (2013) that were measured in 


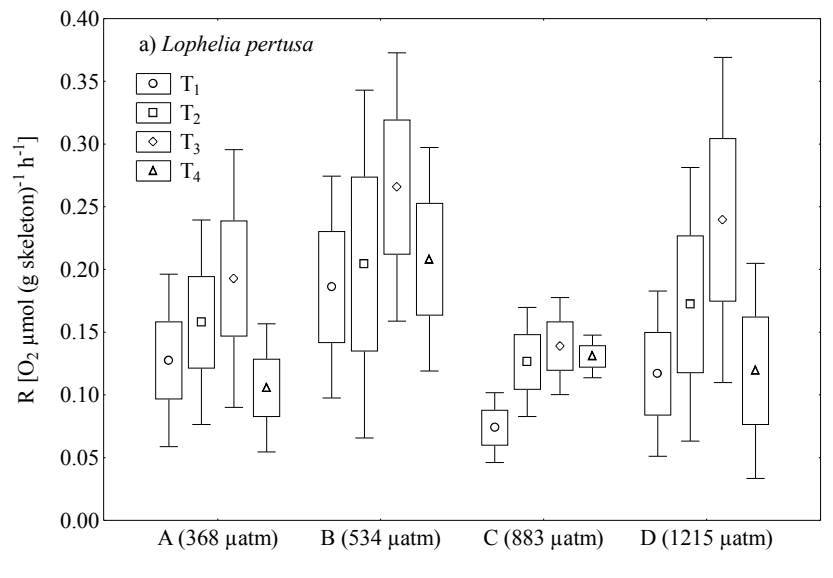

$\mathrm{pCO}_{2}$ treatment

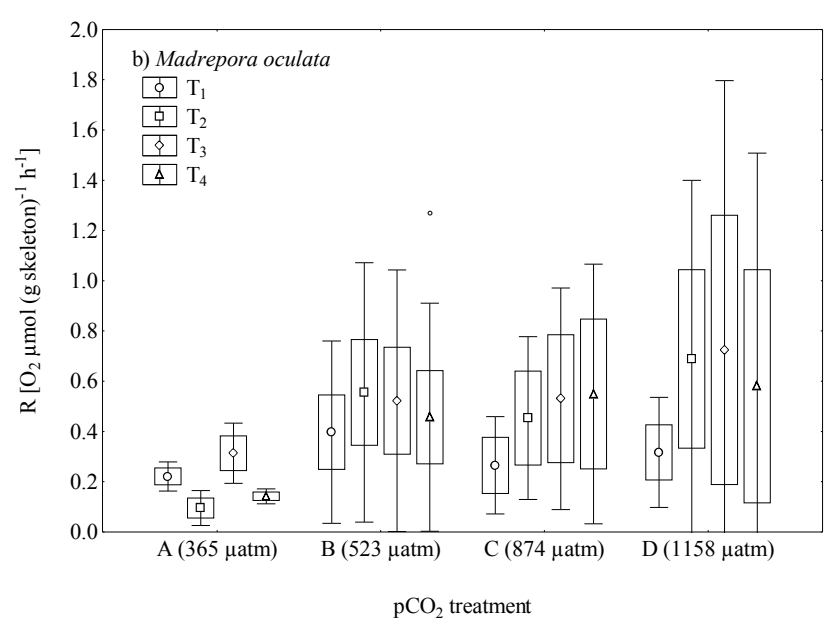

Fig. 1. Respiration rates of (a) L. pertusa (LP) and (b) M. oculata $(\mathrm{MO})$ for repeated measurements $\left(T_{1}-T_{4}\right)$ at four $p \mathrm{CO}_{2}$ treatments (A-D; see Tables 2 and 3). Values for $p \mathrm{CO}_{2}$ treatments A-D (parentheses) are mean at end of incubation (Table 3).

parallel to the respiration rates of this study were taken into consideration for calculating the parameters of the carbonate chemistry at end of the incubation.

Calcification decreases $A_{\mathrm{T}}$ by $2 \times G$ and $C_{\mathrm{T}}$ by $1 \times G$, respiration increases $C_{\mathrm{T}}$ by $1 \times R$ (assuming a respiratory quotient of 1) and ammonium increases $A_{\mathrm{T}}$ by $(14 / 16) \times \mathrm{NH}_{4}$ (Gattuso et al., 1999).

\subsection{Statistical analysis}

Statistical analyses were conducted using the software Statistica 7.0. Data are given as mean \pm standard deviation (SD). For the comparison of carbonate chemistry among the four $p \mathrm{CO}_{2}$ treatments (A-D) of bulk seawater prepared at $T_{1}-T_{4}$, a one-way ANOVA was conducted followed by a Tukey HSD post hoc comparison. A repeated measures ANOVA was used to compare respiration rates at the $4 p \mathrm{CO}_{2}$ levels from $T_{1}$ to $T_{4}$ for each coral fragment.

\section{Results and discussion}

\subsection{Carbonate chemistry}

The $p \mathrm{CO}_{2}$ of bulk seawater prior to the incubations differed from the $p \mathrm{CO}_{2}$ levels that were adjusted by aeration using pre-mixed air- $\mathrm{CO}_{2}$ for treatment $\mathrm{A}(280 \mathrm{ppm})$, B (400 ppm), C (700 ppm) and D (1000 ppm). The seawater $p \mathrm{CO}_{2}$ achieved by aeration was on average $350 \pm 20$, $497 \pm 28,826 \pm 69$ and $1108 \pm 58 \mu$ atm for treatments A-D, respectively (Table 2 ). Therefore, all values tended to be higher than those of air- $\mathrm{CO}_{2}$ mixtures. These levels covered a large range from slightly below ambient to above the level projected for the end of the century (IPPC, 2007). Unsurprisingly, $A_{\mathrm{T}}$ was not affected by changes in $p \mathrm{CO}_{2}$ (one-way ANOVA, $p>0.69)$. The other parameters of the carbonate chemistry $\left(C_{\mathrm{T}}, p \mathrm{CO}_{2}, \mathrm{pH}_{\mathrm{T}}\right.$ and $\left.\Omega_{\mathrm{a}}\right)$ were significantly different between each of the four $p \mathrm{CO}_{2}$ treatment levels (oneway ANOVA, $p \ll 0.001$ and Tukey HSD post hoc comparison, $p \ll 0.05$ for pairwise comparisons between any pair of the four $p \mathrm{CO}_{2}$ treatments).

Also, the changes for parameters of the carbonate chemistry that took place during the $2.5 \mathrm{~h}$ closed-system incubation were estimated as a function of respiration, calcification and ammonium excretion (for details see "Methods" Sect. 2.3.). During the $2.5 \mathrm{~h}$ incubations, there was an average increase of $p \mathrm{CO}_{2}$ of $6 \pm 2 \%$ (range 3 to $13 \%$ ) and an average decrease of $\Omega_{\mathrm{a}}$ of $5 \pm 1 \%$. Changes in the other parameters were below $1 \%$ of the initial values (Table 3 ).

\subsection{Respiration rates at different $p \mathrm{CO}_{2}$ levels and over time}

The respiration rates ranged from 0.074 to $0.266 \mu \mathrm{mol} \mathrm{O}_{2}$ (g skeletal dry weight $)^{-1} \mathrm{~h}^{-1}$ and 0.095 to $0.725 \mu \mathrm{mol} \mathrm{O}$ (g skeletal dry weight $)^{-1} \mathrm{~h}^{-1}$ at different times of incubation and $p \mathrm{CO}_{2}$ treatments for $L$. pertusa and M. oculata, respectively (Fig. 1). Despite the large range of $p \mathrm{CO}_{2}$ levels across the four treatments, there was no effect between $p \mathrm{CO}_{2}$ treatment levels on respiration rates (two-way repeated measures ANOVA, $p=0.767$ and $p=0.357$ for M. oculata and L.pertusa, respectively). For $L$. pertusa, there was an increase in respiration from $T_{1}$ to $T_{3}$ and a decrease again at $T_{4}$ independent of $p \mathrm{CO}_{2}$ levels studied and a significant effect of time of incubation (two-way repeated measures ANOVA, $p$ $\ll 0.001)$. A similar pattern of increasing respiration from $T_{1}$ to $T_{3}$ could be observed for $M$. oculata, but it was not as consistent among the $p \mathrm{CO}_{2}$ treatments as that for $L$. pertusa. In addition, there was no significant effect between repeated measurements $T_{1}-T_{4}$ (two-way repeated measures ANOVA, $p=0.104)$. To our best knowledge, this is the first report of the effect of $p \mathrm{CO}_{2}$ on respiration on the two coldwater coral species $L$. pertusa and $M$. oculata. In contrast to our results, a significant decrease in respiration at elevated $p \mathrm{CO}_{2}$ (D. Piepenburg and M. Bartz, unpublished results) was 
Table 2. Parameters of the carbonate chemistry at the beginning of the incubations. Total alkalinity $\left(A_{\mathrm{T}}\right)$ and dissolved inorganic carbon $\left(C_{\mathrm{T}}\right)$ were measured, while $\mathrm{pH}$ on total scale $\left(\mathrm{pH}_{\mathrm{T}}\right)$, partial pressure of $\mathrm{CO}_{2}\left(p \mathrm{CO}_{2}\right)$ and the aragonite saturation state $\left(\Omega_{\mathrm{a}}\right)$ were calculated. $T$ is the period at which the incubations were performed (at approximately monthly intervals). $T_{1-4}$ displays the pooled data for $T_{1}$ to $T_{4}$.

\begin{tabular}{|c|c|c|c|c|c|c|c|c|c|c|c|c|}
\hline \multirow[t]{2}{*}{$T$} & \multirow[t]{2}{*}{$\begin{array}{c}\stackrel{p \mathrm{CO}_{2}}{\text { treatment }} \\
\text { treatme }\end{array}$} & \multirow[t]{2}{*}{$N$} & \multicolumn{2}{|c|}{$\begin{array}{c}A_{\mathrm{T}} \\
{\left[\mu \mathrm{mol} \mathrm{kg}{ }^{-1}\right]}\end{array}$} & \multicolumn{2}{|c|}{$\begin{array}{c}C_{\mathbf{T}} \\
{\left[\mu \mathrm{mol} \mathrm{kg}{ }^{-1}\right]}\end{array}$} & \multicolumn{2}{|c|}{$\mathrm{pH}_{\mathrm{T}}$} & \multicolumn{2}{|c|}{$\begin{array}{l}p \mathrm{CO}_{2} \\
{[\mu a t m]}\end{array}$} & \multicolumn{2}{|c|}{$\Omega_{\mathrm{a}}$} \\
\hline & & & mean & S.D. & mean & S.D. & mean & S.D. & mean & S.D. & mean & S.D. \\
\hline 1 & A & 3 & 2565 & 1.5 & 2297 & 6.6 & 8.10 & 0.01 & 380 & 11.0 & 2.90 & 0.06 \\
\hline 2 & A & & $\mathrm{n} / \mathrm{a}$ & & $\mathrm{n} / \mathrm{a}$ & & & & & & & \\
\hline 3 & A & 3 & 2548 & 1.6 & 2261 & 3.0 & 8.14 & 0.01 & 342 & 6.1 & 3.08 & 0.04 \\
\hline 4 & A & 3 & 2552 & 7.7 & 2255 & 3.2 & 8.15 & 0.02 & 327 & 14.4 & 3.18 & 0.11 \\
\hline$T_{1}-T_{4}$ & A & 3 & 2555 & 6.5 & 2271 & $\mathbf{1 7 . 5}$ & 8.13 & 0.02 & 350 & 20.3 & 3.05 & 0.10 \\
\hline 1 & B & 3 & 2540 & 0.4 & 2341 & 12.5 & 7.97 & 0.03 & 530 & 34.6 & 2.24 & 0.11 \\
\hline 2 & B & 3 & 2544 & 1.3 & 2341 & 4.6 & 7.98 & 0.01 & 520 & 13.5 & 2.28 & 0.04 \\
\hline 3 & B & 3 & 2549 & 3.3 & 2331 & 1.1 & 8.01 & 0.00 & 481 & 4.8 & 2.42 & 0.02 \\
\hline 4 & B & 3 & 2555 & 7.1 & 2327 & 1.2 & 8.03 & 0.01 & 459 & 16.6 & 2.52 & 0.08 \\
\hline$T_{1}-T_{4}$ & $\mathrm{~B}$ & 4 & 2547 & 4.8 & 2335 & 6.3 & 8.00 & 0.02 & 497 & 27.5 & 2.37 & 0.10 \\
\hline 1 & $\mathrm{C}$ & 3 & 2549 & 1.5 & 2440 & 13.0 & 7.76 & 0.03 & 910 & 75.4 & 1.48 & 0.11 \\
\hline 2 & $\mathrm{C}$ & 3 & 2552 & 4.1 & 2438 & 9.8 & 7.78 & 0.01 & 879 & 33.8 & 1.52 & 0.04 \\
\hline 3 & $\mathrm{C}$ & 3 & 2536 & 1.3 & 2408 & 5.0 & 7.81 & 0.01 & 798 & 21.6 & 1.63 & 0.03 \\
\hline 4 & $\mathrm{C}$ & 3 & 2564 & 2.8 & 2415 & 11.2 & 7.86 & 0.02 & 716 & 38.2 & 1.81 & 0.07 \\
\hline$T_{1}-T_{4}$ & $\mathrm{C}$ & 4 & 2550 & 7.9 & 2425 & 13.6 & 7.80 & 0.03 & 826 & 68.9 & 1.61 & 0.11 \\
\hline 1 & $\mathrm{D}$ & 3 & 2553 & 1.5 & 2482 & 2.2 & 7.67 & 0.01 & 1164 & 28.1 & 1.20 & 0.03 \\
\hline 2 & $\mathrm{D}$ & 3 & 2554 & 7.5 & 2482 & 7.9 & 7.66 & 0.02 & 1169 & 58.9 & 1.20 & 0.05 \\
\hline 3 & $\mathrm{D}$ & 3 & 2538 & 5.6 & 2455 & 3.6 & 7.70 & 0.01 & 1075 & 22.0 & 1.27 & 0.03 \\
\hline 4 & $\mathrm{D}$ & 3 & 2554 & 3.8 & 2463 & 6.3 & 7.72 & 0.02 & 1025 & 50.2 & 1.34 & 0.06 \\
\hline$T_{1}-T_{4}$ & D & 4 & 2549 & 6.0 & 2470 & 11.6 & 7.69 & 0.02 & 1108 & 58.3 & 1.25 & 0.05 \\
\hline
\end{tabular}

mentioned by Form and Riebesell (2012), but no data were provided. A decrease in respiration at elevated $p \mathrm{CO}_{2}$ would be surprising as it would not be in agreement with the hypothesis that more energy must be allocated to up-regulate internal $\mathrm{pH}$ and maintain constant calcification.

\subsection{Respiration and calcification}

To date, calcification is the only parameter investigated with respect to the effects of ocean acidification on cold-water corals. It generally appears to be constant over a large range in $p \mathrm{CO}_{2}$ levels (Thresher et al., 2011; Form and Riebesell, 2012; Maier et al., 2012, 2013). It has been proposed that cold-water corals can up-regulate their internal $\mathrm{pH}$ and maintain a constant rate of calcification even when seawater is undersaturated in aragonite (McCulloch et al., 2012). Since the up-regulation of internal $\mathrm{pH}$ and maintenance of high calcification rates is an energy-requiring process mediated through Ca-ATPase (McConnaughey and Whelan, 1997; Allemand et al., 2004; Zoccola et al., 2004), the question arises whether up-regulation of internal $\mathrm{pH}$ at elevated $p \mathrm{CO}_{2}$ alters the energy balance. For example, more energy would be required to up-regulate the internal $\mathrm{pH}$ if ambient $\mathrm{pH}$ decreased, and it was therefore expected that this would induce a higher rate of respiration. However, the results presented here reveal that respiration is independent of $p \mathrm{CO}_{2}$ level in the corals tested. The response of calcification of the same coral fragments is similar over $p \mathrm{CO}_{2}$ levels ranging from 380 to $930 \mu a t m$ (Maier et al., 2013). Calcification correlates significantly with respiration (Fig. 2), indicating a strong coupling of calcification and general metabolic performance. The slope of the regression equation between skeletal growth $(G)$ and respiration rates $(R)$ was steeper for $L$. pertusa than for $M$. oculata, which suggests that more energy is allocated to calcification in L. pertusa than in M. oculata (Fig. 2).

For zooxanthellate corals, it had been proposed that the energy for calcification is derived to a large part from photosynthesis (Gattuso et al., 1999; Al-Horani et al., 2003), an energy source that is not available to cold-water corals. Due to the logistically challenging access to cold-water coral habitats, no quantitative data are available on the food supply and natural feeding regime of cold-water corals. It is therefore difficult to mimic the in situ feeding during experiments. During the experiments lasting several months, sufficient food was provided in order to avoid starvation, which might impede respiration or calcification as shown in a previous study (Naumann et al., 2011). Abundant food supply was shown 
Table 3. Estimated parameters of the carbonate chemistry at the end of the incubations of coral fragments of L. pertusa (LP) and $M$. oculata (MO). Mean values $A_{\mathrm{T}} 2.5 \mathrm{~h}$ and $C_{\mathrm{T}} 2.5 \mathrm{~h}$ were used to calculate the other parameters of carbonate chemistry $\left(\mathrm{pH}_{\mathrm{T}} 2.5 \mathrm{~h}, p \mathrm{CO}_{2} 2.5 \mathrm{~h}\right.$ and $\Omega_{\mathrm{a}} 2.5 \mathrm{~h}$ ). The difference between the end and the beginning of the incubations is also shown $(\Delta) . T$ is the period at which the incubations were performed (at ca. monthly intervals). $T_{1-4}$ displays the pooled data for $T_{1}$ to $T_{4}$.

\begin{tabular}{|c|c|c|c|c|c|c|c|c|c|c|c|c|c|c|c|}
\hline \multirow[t]{2}{*}{$T$} & \multirow[t]{2}{*}{$\begin{array}{l}p \mathrm{CO}_{2} \\
\text { treatment }\end{array}$} & \multirow[t]{2}{*}{ Coral } & \multirow[t]{2}{*}{$N$} & \multicolumn{3}{|c|}{$\begin{array}{c}A_{\mathrm{T}} 2.5 \mathrm{~h} \\
{\left[\mu \mathrm{molkg}^{-1}\right]}\end{array}$} & \multicolumn{3}{|c|}{$\begin{array}{c}\mathrm{C}_{\mathrm{T}} 2.5 \mathrm{~h} \\
{\left[\mu \mathrm{mol} \mathrm{kg}{ }^{-1}\right]}\end{array}$} & \multicolumn{2}{|c|}{$\mathrm{pH}_{\mathrm{T}} 2.5 \mathrm{~h}$} & \multicolumn{2}{|c|}{$\begin{array}{c}p \mathrm{CO}_{2} 2.5 \mathrm{~h} \\
{[\mu \mathrm{atm}]}\end{array}$} & \multicolumn{2}{|c|}{$\Omega_{\mathrm{a}} 2.5 \mathrm{~h}$} \\
\hline & & & & mean & S.D. & $\Delta$ & mean & S.D. & $\Delta$ & & $\Delta$ & & $\Delta$ & & $\Delta$ \\
\hline 1 & A & LP & 5 & 2560 & 1.37 & -4.63 & 2303 & 8.07 & 5.76 & 8.08 & -0.02 & 398 & 18 & 2.79 & -0.10 \\
\hline 2 & A & LP & 5 & $\mathrm{n} / \mathrm{a}$ & & & $\mathrm{n} / \mathrm{a}$ & & & & & & & & \\
\hline 3 & A & LP & 5 & 2541 & 5.46 & -6.89 & 2269 & 9.15 & 8.61 & 8.11 & -0.03 & 365 & 24 & 2.93 & -0.15 \\
\hline 4 & A & LP & 5 & 2546 & 2.15 & -6.57 & 2259 & 7.76 & 4.77 & 8.14 & -0.02 & 342 & 15 & 3.07 & -0.11 \\
\hline$T_{1-4}$ & $\mathrm{~A}$ & LP & 3 & 2549 & 7.43 & -6.03 & 2277 & 17.06 & 5.77 & 8.11 & $-\mathbf{0 . 0 2}$ & 368 & 19 & 2.93 & -0.12 \\
\hline 1 & $\mathrm{~B}$ & LP & 4 & 2535 & 2.73 & -4.92 & 2348 & 3.99 & 6.82 & 7.95 & -0.02 & 563 & 33 & 2.13 & -0.11 \\
\hline 2 & B & LP & 4 & 2539 & 3.01 & -5.22 & 2348 & 4.07 & 6.26 & 7.96 & -0.02 & 552 & 33 & 2.17 & -0.11 \\
\hline 3 & B & LP & 4 & 2543 & 2.75 & -5.85 & 2344 & 11.63 & 13.40 & 7.97 & -0.04 & 530 & 49 & 2.25 & -0.18 \\
\hline 4 & B & LP & 4 & 2551 & 3.31 & -4.39 & 2337 & 7.08 & 9.90 & 8.00 & -0.03 & 492 & 33 & 2.39 & -0.13 \\
\hline$T_{1-4}$ & $\mathrm{~B}$ & LP & 4 & 2542 & 4.80 & -5.09 & 2344 & 3.76 & 9.10 & 7.97 & $-\mathbf{0 . 0 3}$ & 534 & 37 & 2.23 & -0.13 \\
\hline 1 & $\mathrm{C}$ & LP & 4 & 2543 & 2.96 & -5.27 & 2442 & 3.45 & 2.50 & 7.74 & -0.02 & 952 & 43 & 1.41 & -0.07 \\
\hline 2 & $\mathrm{C}$ & LP & 4 & 2545 & 6.86 & -7.26 & 2443 & 6.33 & 5.14 & 7.75 & -0.03 & 947 & 68 & 1.42 & -0.10 \\
\hline 3 & $\mathrm{C}$ & LP & 4 & 2525 & 10.07 & -10.87 & 2412 & 7.62 & 4.74 & 7.78 & -0.04 & 872 & 74 & 1.50 & -0.13 \\
\hline 4 & $\mathrm{C}$ & LP & 4 & 2562 & 1.76 & -2.16 & 2424 & 3.47 & 8.61 & 7.84 & -0.03 & 762 & 46 & 1.72 & -0.09 \\
\hline$T_{1-4}$ & $\mathrm{C}$ & LP & 4 & 2544 & 9.61 & -6.39 & 2430 & 12.14 & 5.25 & 7.78 & $-\mathbf{0 . 0 3}$ & 883 & 58 & 1.51 & -0.10 \\
\hline 1 & $\mathrm{D}$ & LP & 4 & 2551 & 1.81 & -2.64 & 2489 & 2.89 & 6.97 & 7.64 & -0.03 & 1245 & 81 & 1.13 & -0.07 \\
\hline 2 & $\mathrm{D}$ & LP & 4 & 2547 & 5.20 & -6.72 & 2491 & 4.22 & 8.58 & 7.62 & -0.04 & 1296 & 127 & 1.09 & -0.11 \\
\hline 3 & $\mathrm{D}$ & LP & 4 & 2527 & 6.37 & -10.75 & 2463 & 13.35 & 8.19 & 7.64 & -0.05 & 1214 & 140 & 1.14 & -0.14 \\
\hline 4 & $\mathrm{D}$ & LP & 4 & 2544 & 3.82 & -9.56 & 2465 & 5.95 & 1.86 & 7.69 & -0.03 & 1104 & 79 & 1.25 & -0.09 \\
\hline$T_{1-4}$ & $\mathrm{D}$ & LP & 4 & 2542 & 7.66 & -7.42 & 2477 & 12.93 & 6.40 & 7.65 & -0.04 & 1215 & 107 & 1.15 & -0.10 \\
\hline 1 & A & MO & 3 & 2561 & 2.16 & -3.43 & 2303 & 6.59 & 6.37 & 8.08 & -0.02 & 397 & 17 & 2.80 & -0.09 \\
\hline 2 & A & MO & 3 & $\mathrm{n} / \mathrm{a}$ & & & $\mathrm{n} / \mathrm{a}$ & & & & & & & & \\
\hline 3 & A & MO & 3 & 2541 & 2.96 & -7.74 & 2266 & 1.89 & 4.72 & 8.12 & -0.02 & 360 & 19 & 2.95 & -0.12 \\
\hline 4 & $\mathrm{~A}$ & MO & 3 & 2546 & 3.44 & -6.46 & 2256 & 1.37 & 1.17 & 8.14 & -0.01 & 337 & 10 & 3.10 & -0.08 \\
\hline$T_{1-4}$ & A & MO & 3 & 2549 & 8.13 & $-\mathbf{5 . 8 8}$ & 2275 & 19.00 & 4.08 & 8.11 & -0.02 & 365 & 15 & 2.95 & -0.10 \\
\hline 1 & B & MO & 6 & 2537 & 1.69 & -3.16 & 2346 & 3.00 & 4.70 & 7.96 & -0.02 & 551 & 21 & 2.17 & -0.07 \\
\hline 2 & B & MO & 6 & 2540 & 2.57 & -4.40 & 2347 & 4.59 & 5.50 & 7.96 & -0.02 & 547 & 27 & 2.19 & -0.09 \\
\hline 3 & B & MO & 6 & 2538 & 10.38 & -10.82 & 2333 & 5.30 & 2.44 & 7.99 & -0.02 & 511 & 30 & 2.30 & -0.12 \\
\hline 4 & $\mathrm{~B}$ & MO & 6 & 2549 & 3.52 & -5.77 & 2331 & 3.32 & 4.59 & 8.01 & -0.02 & 481 & 22 & 2.42 & -0.10 \\
\hline$T_{1-4}$ & $\mathrm{~B}$ & MO & 4 & 2541 & 4.14 & -6.04 & 2339 & 7.11 & 4.31 & 7.98 & -0.02 & 523 & 25 & 2.27 & -0.10 \\
\hline 1 & $\mathrm{C}$ & MO & $J$ & 2546 & 0.73 & -2.66 & 2443 & 3.46 & 3.04 & 7.75 & -0.01 & 942 & 32 & 1.43 & -0.05 \\
\hline 2 & $\mathrm{C}$ & MO & 3 & 2550 & 0.37 & -2.21 & 2445 & 4.91 & 7.36 & 7.75 & -0.02 & 931 & 52 & 1.45 & -0.07 \\
\hline 3 & $\mathrm{C}$ & MO & 3 & 2532 & 2.25 & -4.21 & 2415 & 6.19 & 7.51 & 7.79 & -0.03 & 853 & 56 & 1.53 & -0.09 \\
\hline 4 & $\mathrm{C}$ & MO & 3 & 2560 & 1.19 & -4.50 & 2424 & 8.39 & 8.32 & 7.83 & -0.03 & 770 & 55 & 1.70 & -0.11 \\
\hline$T_{1-4}$ & $\mathrm{C}$ & MO & 4 & 2547 & 7.97 & $-\mathbf{3 . 3 9}$ & 2432 & 12.21 & 6.56 & 7.78 & -0.02 & 874 & 49 & 1.53 & -0.08 \\
\hline 1 & $\mathrm{D}$ & MO & 4 & 2550 & 1.37 & -2.72 & 2484 & 0.82 & 1.90 & 7.65 & -0.02 & 1211 & 47 & 1.16 & -0.04 \\
\hline 2 & $\mathrm{D}$ & MO & 4 & 2552 & 2.05 & -1.83 & 2487 & 4.53 & 4.82 & 7.65 & -0.02 & 1220 & 51 & 1.15 & -0.05 \\
\hline 3 & $\mathrm{D}$ & MO & 4 & 2536 & 1.60 & -1.23 & 2460 & 7.56 & 5.15 & 7.68 & -0.02 & 1122 & 48 & 1.22 & -0.05 \\
\hline 4 & $\mathrm{D}$ & MO & 4 & 2548 & 1.99 & -5.29 & 2465 & 7.00 & 2.73 & 7.70 & -0.02 & 1077 & 51 & 1.28 & -0.06 \\
\hline$T_{1-4}$ & $\mathrm{D}$ & MO & 4 & 2547 & 5.23 & -2.77 & 2474 & 11.27 & 3.65 & 7.67 & -0.02 & 1158 & 49 & 1.20 & -0.05 \\
\hline
\end{tabular}




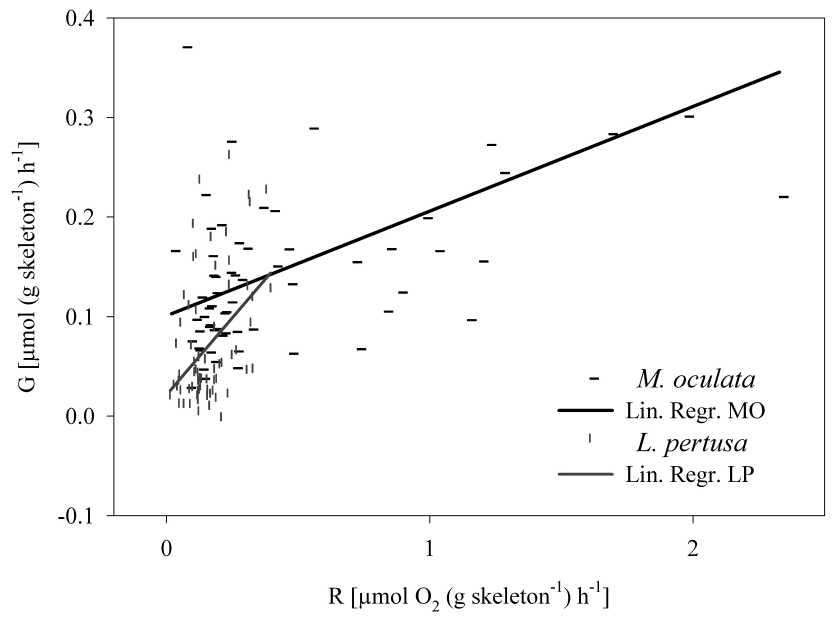

Fig. 2. Rate of calcification ( $G$, from Maier et al., 2013) as a function of respiration rate $(R)$ for $L$. pertusa (LP) and $M$. oculata (MO). The equations of the regression lines are $G_{\mathrm{LP}}=0.0217+0.3091 \times R ;(r=0.4182 ; p=0.0004 ; n=68)$, and $\quad G_{\mathrm{MO}}=0.1009+0.1051 \times R ;(r=0.4877 ; p=0.00004$; $n=64)$.

to counterbalance a negative response of invertebrates to elevated $p \mathrm{CO}_{2}$ both in the laboratory and in the field (e.g. Thomsen et al., 2013). However, it was not an issue in the present experiment as the continuous flow of water exponentially diluted the prey concentration. With a dilution factor of $10.7 \% \mathrm{~h}^{-1}$ (flow rate of $32 \mathrm{~mL} \mathrm{~h}^{-1}$ and a maintenance volume of $300 \mathrm{~mL}$ ), the corals received an initial pulse of food which decreases by $93.3 \% \mathrm{~d}^{-1}$. This means that after one day, only $6.7 \%$ of prey is left, and after a further two or three days, before vials were cleaned and new food was provided, prey is reduced to $0.44 \%$ and $0.03 \%$ of the initial prey concentration, respectively. It is unclear, what caused the synchronous increase of calcification and respiration during the 2-3-month-long experiment at different $p \mathrm{CO}_{2}$ levels (this study and Maier et al., 2013). One likely explanation is that the regular feeding triggered an increase in coral metabolism (calcification and respiration). Whatever the cause of this increase is, it was observed in all $p \mathrm{CO}_{2}$ treatments and resulted in large changes in the rates of respiration and calcification over time. The possibility that an effect of $p \mathrm{CO}_{2}$ was masked due to an unrealistic feeding regime due to either starvation or overfeeding can be excluded.

\subsection{Energy requirements and temperature}

A study of the cold-water coral Desmophyllum dianthus, revealed that both respiration and calcification rates were lower in starved than fed colonies (Naumann et al., 2011). Also, feeding increases both the skeletal and tissue growth in zooxanthellate corals (FerrierPagès et al., 2003; Houlbrèque et al., 2003; RodolfoMetalpa et al., 2008). Mean respiration rates pooled for $p \mathrm{CO}_{2}$ treatment levels and repeated measurements $\left(T_{1}-T_{4}\right)$ were $0.16 \pm 0.08 \mu \mathrm{mol} \mathrm{O}_{2}$ (g skeletal dry weight $)^{-1} \mathrm{~h}^{-1}$ and $0.45 \pm 0.45 \mu \mathrm{mol} \mathrm{O}_{2}$ (g skeletal dry weight $)^{-1} \mathrm{~h}^{-1}$ for L. pertusa and $M$. oculata, respectively (Table 1). So far, only one study (from Mingulay Reef, northeast Atlantic) has reported the respiration rates for $L$. pertusa (Dodds et al., 2007) and respiration rates of $M$. oculata have, to our best knowledge, never been measured. For L. pertusa, Dodds et al. (2007) reported respiration rates of specimens from the NE Atlantic at ambient temperature that were higher than those measured here in individuals collected from the Mediterranean Sea $\left(0.23\right.$ vs. $0.16 \mu \mathrm{mol} \mathrm{O}_{2}$ (g skeletal dry weight $)^{-1} \mathrm{~h}^{-1}$, Table 1 ). This is surprising since Mediterranean cold-water corals live in habitats that are, on average, $4{ }^{\circ} \mathrm{C}$ warmer than temperatures reported at the Mingulay collection site $\left(13\right.$ vs. $\left.9^{\circ} \mathrm{C}\right)$. Furthermore, Dodds et al. (2007) showed that respiration increased by $\left.50 \%(0.23 \text { to } 0.33 \mu \mathrm{mol} \text { (g skeletal dry weight })^{-1} \mathrm{~h}^{-1}\right)$ with an increase of $2{ }^{\circ} \mathrm{C}$ (from 9 to $11^{\circ} \mathrm{C}$ ) suggesting that respiration rates for Mediterranean cold-water corals subjected to $13{ }^{\circ} \mathrm{C}$ would be expected to be well above those found for North Atlantic specimens. The temperature coefficient of respiration $\left(Q_{10}\right)$ of Mediterranean $L$. pertusa is lower than that of North Atlantic L. pertusa (on average 4.0 and 7.2, respectively, SI 1 and Dodds et al., 2007). A lower $Q_{10}$ might be indicative of acclimation (Barnes, 2001), and the lower $Q_{10}$ for a temperature of up to $16.7^{\circ} \mathrm{C}$ could mean that cold-water corals, due to their adaptation to the higher Mediterranean temperature, might be less sensitive to temperature changes than their North Atlantic congeners. Naumann et al. (2013) reported a high thermal tolerance of calcification in two Mediterranean deep-sea corals. Compared to an ambient temperature of about $12^{\circ} \mathrm{C}$, at $17.5^{\circ} \mathrm{C}$, calcification increased in Dendrophyllia cornigera and was similar in Desmophyllum dianthus.

This is the first study to measure the respiration rates of $M$. oculata and, consequently, no data for comparison are available. Due to the lack of data from other regions and temperature ranges, it remains unknown whether $M$. осиlata is better adapted to the relatively warm temperatures experienced in Mediterranean Sea deep-water habitats. However, respiration not only depends on temperature but also on other parameters, e.g. salinity (Ferrier-Pagès et al., 1999), food availability (Naumann et al., 2011) and intrinsic factors regulating metabolism (Hochachka and Somero, 2002). $M$. oculata is more commonly found in the Mediterranean than L. pertusa (Freiwald et al., 2009; Gori et al., 2013), which suggests that it is better adapted to environmental factors prevailing in that region. Respiration rate normalized by the skeletal dry weight was 2.7 times higher in $M$. oculata than in L. pertusa, and with higher respiration, more energy would be required to sustain coral metabolism. However, respiration is a surface-dependent process (Barnes, 2001), and skeletal weight might thus not be a good biomass estimator to normalize metabolic processes. Surface area, tissue biomass 
or number of polyp are likely more suitable units to relate metabolic processes or prey capture. The ratio of skeletal area versus polyp number is approximately 3 times higher in L. pertusa than in M. oculata (373 vs. $126 \mathrm{~mm}^{2}$ polyp ${ }^{-1}$ ) (Maier et al., 2011). Using this ratio and the ratio of polyp number to skeletal weight (Table 1) reveals that respiration normalized to surface is similar in L. pertusa and M. oculata (0.022 and $0.024 \mu \mathrm{mol} \mathrm{O} \mathrm{cm}^{-2} \mathrm{~h}^{-1}$, respectively).

Since the food uptake plays a significant role for both respiration and calcification (Naumann et al., 2011), the similar respiration rate for the two species does not allow for any conclusion to be drawn as to whether both species would be similarly well acclimatized to high Mediterranean temperatures. L. pertusa has bigger, but less numerous, polyps than $M$. oculata, which might indicate that the efficiency of prey capture differs in the two species, depending on the amount and size of food available. Food capture rates were not measured in the present study, but Tsounis et al. (2010) reported total carbon uptake rates of 3731 and $1072 \mu \mathrm{g} \mathrm{C}$ polyp $^{-1} \mathrm{~h}^{-1}$, respectively, in $L$. pertusa and $M$. oculata from the Mediterranean Sea (Tsounis et al., 2010). This translates to a carbon uptake of $83.4 \mu \mathrm{mol} \mathrm{C} \mathrm{cm}{ }^{-2} \mathrm{~h}^{-1}$ and $70.9 \mu \mathrm{mol} \mathrm{C} \mathrm{cm}{ }^{-2} \mathrm{~h}^{-1}$ (Maier et al., 2011, and Table 1). Therefore, both species have a similar prey capture efficiency despite the difference of polyp size, which is possibly compensated by the higher number of polyps per unit surface area or skeletal weight in M. oculata. It can therefore be inferred that the two species ingested a similar amount of $\mathrm{C}$ in our experiment. It should be pointed out that calcification rates normalized to surface area were also similar in the two species $(0.010$ and $0.008 \mu \mathrm{mol} \mathrm{CaCO} \mathrm{cm}^{-2} \mathrm{~h}^{-1}$ for L. pertusa and M. oculata, respectively, Maier et al., 2013). There is relative uniformity of the two species with the overall lack of response to $p \mathrm{CO}_{2}$, as well as the similar rates of carbon uptake, respiration, calcification and the reported increase over time of respiration rates independent of $p \mathrm{CO}_{2}$. This could indicate that $M$. oculata and $L$. pertusa will exhibit a similar response to future global environmental change. However, more studies are needed to confirm this hypothesis.

\subsection{Perspective on the response of cold-water corals to global environmental change}

In the range of $p \mathrm{CO}_{2}$ studied so far, up to $1215 \mu \mathrm{atm}$, no significant change in respiration was found as a function of increasing $p \mathrm{CO}_{2}$. However, to better predict future responses of organisms to global change, it is critical to identify potential interactive effects between ocean acidification and other parameters such as temperature and food availability. Considering all published information, a potential tipping point for calcification of the two cold-water species would be above a $p \mathrm{CO}_{2}$ of $1000 \mu \mathrm{atm}$ and at an $\Omega_{\mathrm{a}}$ below 1 (Maier et al., 2009, 2012, 2013; Thresher et al., 2011; Form and Riebesell, 2012; McCulloch et al., 2012, \#3512), and the same might be true for the respiration response as indicated in the present study. For calcification rates of $L$. pertusa, there is indirect evidence from short-term closed system incubations (Maier et al., 2009) that this tipping point would be well above $1000 \mathrm{ppm}$ and at an $\Omega_{\mathrm{a}}$ below 0.9 (Table 3, Maier et al., 2009).

This study provides the first evidence that respiration rates of cold-water corals are not affected by elevated $p \mathrm{CO}_{2}$ and that the ability of our two target species to maintain rates of calcification at high $p \mathrm{CO}_{2}$ was not via compensatory responses in metabolic losses. This means that for the maintenance of high calcification rates over a large range of $p \mathrm{CO}_{2}$ of up to $1000 \mathrm{ppm}$, there is no evidence for a direct energy allocation from food uptake to calcification in order to compensate for higher energy required to maintain calcification constant despite a decrease in $\mathrm{pH}$. However, it is possible that as-yet-unidentified changes in metabolic pathways enable a more efficient supply of necessary energy for $\mathrm{pH}$ upregulation to maintain constant calcification rates at increasing $p \mathrm{CO}_{2}$. It is also possible that cold-water corals use lipid reserves, which would be reflected in a lower respiratory quotient. However, this would mean that respiration would not be sustainable over a longer timescale, as lipid reserves would get exhausted and would not be replenished due to the higher energy allocated to calcification. Therefore, future studies are needed to investigate in more detail the mechanisms that allow for cold-water corals to cope with high $p \mathrm{CO}_{2}$ levels. For zooxanthellate corals, molecular techniques looking at gene expression revealed that ocean acidification strongly suppresses metabolism and enhanced extracellular organic matrix synthesis and had complex effects on genes involved in calcification (Moya et al., 2012; Kaniewska et al., 2012). The response of other parameters important for coral functioning, e.g. reproduction and resilience to other environmental stressors (food reduction, temperature rise, predation, etc.) also needs attention in order to better predict whether and how cold-water corals will be able to cope with global environmental changes.

\section{Supplementary material related to this article is

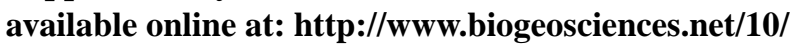 5671/2013/bg-10-5671-2013-supplement.pdf.}

Acknowledgements. We would like to thank the captain, crew and scientific shipboard staff of RV Minibex (COMEX). Cruises on RV Minibex were part of a project on canyons of the Mediterranean Sea (MedSeaCan) lead by the French Marine Protected Areas Agency (AAMP), France. Our thanks go to A. Schubert for help with the experiments. Financial support was provided by the European Commission through a Marie Curie Fellowship to CM (MECCA, project no 220299) and the project COMP via the Prince Albert II of Monaco Foundation. FB acknowledges support from the German Academic Exchange Service (DAAD). This work 
is a contribution to the "European Project on Ocean Acidification" (EPOCA) which received funding from the European Community's Seventh Framework Programme (FP7/2007-2013) under grant agreement no. 211384.

Edited by: G. Herndl

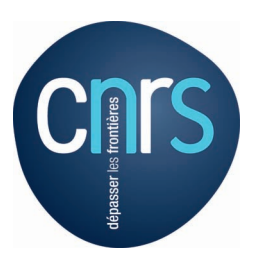

The publication of this article is financed by CNRS-INSU.

\section{References}

Al-Horani, F. A., Al-Moghrabi, S. M., and de Beer. D.: The mechanism of calcification and its relation to photosynthesis and respiration in the scleractinian coral Galaxea fascicularis, Mar. Biol., 142, 419-426, 2003.

Allemand, D., Ferrier-Pagès, C., Furla, P., Houlbrèque, F., Puverel, S., Reynaud, S., Tambutté, É., Tambutté, S., and Zoccola, D.: Biomineralisation in reef-building corals: from molecular mechanisms to environmental control, C. R. Palevol. 3, 453-467, 2004.

Barnes, R. S. K.: The invertebrates: a synthesis, Blackwell Science Ltd, Oxford, 2001.

Caldeira, K. and Wickett, M. E.: Anthropogenic carbon and ocean pH, Nature, 425, 365-365, doi:10.1038/425365a, 2003

Cao, L., Caldeira, K., and Jain, A. K.: Effects of carbon dioxide and climate change on ocean acidification and carbonate mineral saturation, Geophys. Res. Lett., 34, L05607, doi:10.1029/2006GL028605, 2007.

Davies, A. J., Wisshak, M., Orr, J. C., and Roberts, J. M. Predicting suitable habitat for the cold-water coral Lophelia pertusa (Scleractinia), Deep-Sea Res. Pt. I, 55, 1048-1062, 2008.

Delibrias, G. and Taviani, M.: Dating the death of Mediterranean deep-sea scleractinian corals, Mar. Geol., 62, 175-180, 1985.

Dodds, L. A., Roberts, J. M., Taylor, A. C., and Marubini, F.: Metabolic tolerance of the cold-water coral Lophelia pertusa (Scleractinia) to temperature and dissolved oxygen change, J. Exp. Mar. Biol. Ecol., 349, 205-214, 2007.

Feely, R. A., Sabine, C. L., Lee, K., Berelson, W., Kleypas, J., Fabry, V. J., and Millero, F. J.: Impact of anthropogenic $\mathrm{CO}_{2}$ on the $\mathrm{CaCO}_{3}$ system in the oceans, Science, 305, 362-366, 2004.

Ferrier-Pagès, C., Gattuso, J.-P., and Jaubert, J.: Effect of small variations in salinity on the rates of photosynthesis and respiration of the zooxanthellate coral Stylophora pistillata, Mar. Ecol.-Prog. Ser., 181, 309-314, 1999.

Ferrier-Pagès, C., Witting, J., Tambutté, E., and Sebens, K. P.: Effect of natural zooplankton feeding on the tissue and skeletal growth of the scleractinian coral Stylophora pistillata, Coral Reefs, 22, 229-240, 2003.

Form, A. U. and Riebesell, U.: Acclimation to ocean acidification during long-term $\mathrm{CO}_{2}$ exposure in the cold-water coral Lophelia pertusa, Glob. Change Biol., 18, 843-853, doi:10.1111/j.13652486.2011.02583.x, 2012.

Freiwald, A., Beuck, L., Rüggeberg, A., Taviani, M., and Hebbeln, D.: The white coral community in the central Mediterranean Sea revealed by ROV surveys, Oceanography, 22, 36-52, 2009.

Gattuso, J.-P., Allemand, D., and Frankignoulle, M.: Photosynthesis and calcification at cellular, organismal and community levels in coral reefs: A review on interactions and control by carbonate chemistry, Amer. Zool., 39, 160-183, 1999.

Goreau, T. F.: The physiology of skeleton formation in corals. I. A method for measuring the rate of calcium deposition by corals under different conditions, Biol. Bull. 116, 59-75, 1959.

Gori, A., Orejas, C., Madurell, T., Bramanti, L., Martins, M., Quintanilla, E., Marti-Puig, P., Lo Iacono, C., Puig, P., Requena, S., Greenacre, M., and Gili, J. M.: Bathymetrical distribution and size structure of cold-water coral populations in the Cap de Creus and Lacaze-Duthiers canyons (northwestern Mediterranean), Biogeosciences, 10, 2049-2060, doi:10.5194/bg-102049-2013, 2013.

Guinotte, J. M., Orr, J., Cairns, S., Freiwald, A., Morgan, L., and George, R.: Will human-induced changes in seawater chemistry alter the distribution of deep-sea scleractinian corals?, Front. Ecol. Environ., 4, 141-146, 2006.

Hochachka, P. W. and Somero, G. N.: Biochemical adaptation: mechanism and process in physiological evolution, Oxford University Press, New York, New York, USA, 2002.

Houlbrèque, F., Tambutté, E., and Ferrier-Pagès, C.: Effect of zooplankton availability on the rates of photosynthesis, and tissue and skeletal growth in the scleractinian coral Stylophora pistillata, J. Exp. Mar. Biol. Ecol., 296, 145-166, 2003.

IPPC: Climate change 2007: the physical science basis, Cambridge University Press, Cambridge, UK, New York, NY, USA, 2007.

Kaniewska, P., Campbell, P. R., Kline, D. I., RodriguezLanetty, M., Miller, D. J., Dove, S., and Hoegh-Guldberg, O.: Major cellular and physiological impacts of ocean acidification on a reef building coral, PLOS One, 7, e34659, doi:10.1371/journal.pone.0034659, 2012.

Khatiwala, S., Primeau, F., and Hall, T.: Reconstruction of the history of anthropogenic $\mathrm{CO}_{2}$ concentrations in the ocean, Nature, 462, 346-349, 2009.

Kleypas, J. A., McMacus, J. W., and Meñez, L. A. B.: Environmental limits to coral reef development: Where do we draw the line?, Amer. Zool., 39, 146-159, 1999.

Lavigne, H. and Gattuso, J.-P.: seacarb: seawater carbonate chemistry with R. R package version 2.4., http://CRAN.R-project.org/ package $=$ seacarb, (last access: 22 February 2013), 2011.

Maier, C., Hegeman, J., Weinbauer, M. G., and Gattuso, J.-P.: Calcification of the cold-water coral Lophelia pertusa, under ambient and reduced $\mathrm{pH}$, Biogeosciences, 6, 1671-1680, doi:10.5194/bg6-1671-2009, 2009.

Maier, C., de Kluijver, A., Agis, M., Brussaard, C. P. D., van Duyl, F. C., and Weinbauer, M. G.: Dynamics of nutrients, total organic carbon, prokaryotes and viruses in onboard incubations of coldwater corals, Biogeosciences, 8, 2609-2620, doi:10.5194/bg-82609-2011, 2011.

Maier, C., Watremez, P., Taviani, M., Weinbauer, M. G., and Gattuso, J.-P.: Calcification rates and the effect of ocean acidification on Mediterranean cold-water corals, P. Roy. Soc. Lond., B, 279, 1713-1723, doi:10.1098/rspb.2011.1763, 2012.

Maier, C., Schubert, A., Berzunza Sanchez, M. M., Weinbauer, M. G., Watremez, P., and Gattuso, J.-P.: End of the century $p \mathrm{CO}_{2}$ levels do not impact calcification in Mediterranean cold-water corals, PLoS ONE, 8, e62655, 
doi:10.1371/journal.pone.0062655, 2013.

McConnaughey, T. A. and Whelan, J. F.: Calcification generates protons for nutrient and bicarbonate uptake, Earth Sci. Rev., 42, 95-117, 1997.

McCulloch, M., Trotter, J., Montagna, P., Falter, J., Dunbar, R., Freiwald, A., Fösterra, G., Lopez Correa, M., Maier, C., Rüggeberg, A., and Taviani, M.: Resilience of cold-water scleractinian corals to ocean acidification: Boron isotopic systematics of $\mathrm{pH}$ and saturation state up-regulation, Geochim. Cosmochim. Ac., 87, 2134, doi:10.1016/j.gca.2012.03.027, 2012.

Moya, A., Huisman, L., Ball, E. E., Hayward, D. C., Grasso, L. C., Chua, C. M., Woo, H. N., Gattuso, J.-P., Forêt, S., and Miller, D. J.: Whole transcriptome analysis of the coral Acropora millepora reveals complex responses to $\mathrm{CO}_{2}$-driven acidification during the initiation of calcification, Mol. Ecol., 21, 2440-2454, 2012.

Naumann, M. S., Orejas, C., Wild, C., and Ferrier-Pagès, C.: First evidence for zooplankton feeding sustaining key physiological processes in a scleractinian cold water coral, J. Exp. Mar. Biol. Ecol., 214, 3570-3576, 2011.

Orejas, C., Gori, A., Iacono, C. L., Puig, P., Gili, J.-M., and Dale, M. R. T.: Cold-water corals in the Cap de Creus canyon, northwestern Mediterranean: spatial distribution, density and anthropogenic impact, Mar. Ecol.-Prog. Ser., 397, 37-51, 2009.

Orr, J. C., Fabry, V. J., Aumont, O., Bopp, L., Doney, S. C., Feely, R. A., Gnanadesikan, A., Gruber, N., Ishida, A., Joos, F., Key, R. M., Lindsay, K., Maier-Reimer, E., Matear, R., Monfray, P., Mouchet, A., Najjar, R. G., Plattner, G.-K., Rodgers, K.B., Sabine, C.L., Sarmiento, J. L., Schlitzer, R., Slater, R. D., Totterdell, I. J., Weirig, M.-F., Yamanaka, Y., and Yool, A.: Anthropogenic ocean acidification over the twenty-first century and its impact on calcifying organisms, Nature, 437, 681-686, 2005.

Roberts, J. M., Wheeler, A. J., and Freiwald, A.: Reefs of the deep: The biology and geology of cold-water coral ecosystems, Science, 312, 543-547, 2006.

Rodolfo-Metalpa, R., Peirano, A., Houlbrèque, F., Abbate, M., and Ferrier-Pagès, C.: Effects of temperature, light and heterotrophy on the growth rate and budding of the temperate coral Cladocora caespitosa, Coral Reefs, 27, 17-25, 2008.
Sabine, C. L., Feely, R. A., Gruber, N., Key, R. M., Lee, K., Bullister, J. L., Wanninkhof, R., Wong, C. S., Wallace, D. W. R., Tilbrook, B., Millero, F. J., Peng, T.-H., Kozyr, A., Ono, T., and Rios, A. F.: The oceanic sink for anthropogenic $\mathrm{CO}_{2}$, Science, 305, 367-371, 2004.

Taviani, M., Freiwald, A., and Zibrowius, H.: Deep coral growth in the Mediterranean Sea: an overview. In: Cold-water corals and ecosystems, edited by: Freiwald, A. and Roberts, J. M., SpringerVerlag, Berlin Heidelberg, 137-156, 2005a.

Taviani, M., Remia, A., Corselli, C., Freiwald, A., Malinverno, E., Mastrototaro, F., Savini, A., and Tursi, A.: First geo-marine survey of living cold-water Lophelia reefs in the Ionian Sea (Mediterranean basin), Facies, 50, 409-417, 2005 b.

Thomsen, J., Casties, I., Pansch, C.Körtzinger, A., and Melzner, F.: Food availability outweighs ocean acidification effects in juvenile Mytilus edulis: laboratory and field experiments, Glob. Change Biol., 19, 1017-1027, doi:10.1111/gcb.12109, 2013

Thresher, R. E., Tilbrook, B., Fallon, S., Wilson, N. C., and Adkins, J.: Effects of chronic low carbonate saturation levels on the distribution, growth and skeletal chemistry of deep-sea corals and other seamount megabenthos, Mar. Ecol.-Prog. Ser., 442, 87-99, 2011.

Tsounis, G., Orejas, C., Reynaud, S., Gili, J.-M., Allemand, D., and Ferrier-Pagès, C.: Prey-capture rates in four Mediterranean coldwater corals, Mar. Ecol.-Prog. Ser., 398, 140-155, 2010.

Tursi, A., Mastrototaro, F., Matarrese, A., Maiorano, P., and D'Onghia, G.: Biodiversity of the white coral reefs in the Ionian Sea (Central Mediterranean), Chem. Ecol., 20, 107-116, 2004.

Zoccola, D., Tambutté, E., Kulhanek, E., Puverel, S., Scimeca, J.C., Allemand, D., and Tambutté, S.: Molecular cloning and localization of a PMCA P-type calcium ATPase from the coral Stylophora pistillata, Biochim. Biophys. Acta, 1663, 117-126, 2004. 